\title{
Evaluation of Weed Incidence and Biomass in Coffee Intercropped with Oil Palm in Avenue and Hollow Square Arrangement in Nigeria
}

\author{
A. O. Famaye, S. A. Adeosun, K. O. Ayegboyin, K. B. Adejobi, 0. S. O. Akanbi, A. F. Okunade \\ Cocoa Research Institute of Nigeria (CRIN), Ibadan, Oyo State, Nigeria \\ Email: tunmos2010@yahoo.com
}

How to cite this paper: Famaye, A.O., Adeosun, S.A., Ayegboyin, K.O., Adejobi, K.B., Akanbi, O.S.O. and Okunade, A.F. (2020) Evaluation of Weed Incidence and Biomass in Coffee Intercropped with Oil Palm in Avenue and Hollow Square Arrangement in Nigeria. American Journal of Plant Sciences, 11, 276-284.

https://doi.org/10.4236/ajps.2020.112021

Received: November 28, 2019

Accepted: February 25, 2020

Published: February 28, 2020

Copyright $\odot 2020$ by author(s) and Scientific Research Publishing Inc. This work is licensed under the Creative Commons Attribution International License (CC BY 4.0).

http://creativecommons.org/licenses/by/4.0/ (c) (i) Open Access

\begin{abstract}
Weed incidence and biomass in tree crop plantations are mainly influenced by environmental, farm management practices and cropping systems. Manipulation of intercropping systems to improve weed management in coffee intercropped with oil palm requires a better understanding of spatial and temporal dynamics of weeds. To evaluate the effect of weed incidence and biomass in coffee intercropped with oil palm in avenue and hollow square arrangement, a study was carried out in Cocoa Research Institute of Nigeria (CRIN) in two locations. The locations are Idi-Ayunre $\left(7^{\circ} 25^{\prime} \mathrm{N}, 3^{\circ} 24^{\prime} \mathrm{E}\right)$ (an alfisol) and Uhonmora $\left(6^{\circ} 5^{\prime} \mathrm{N}, 5^{\circ} 50^{\prime} \mathrm{E}\right)$ (ultisol) in rainforest and derived savannah parts of Nigeria respectively. The experiment had three treatments comprising coffee sole (control), coffee with oil palm (Hollow square) arrangement and coffee with oil palm (Avenue) planting. Coffee was planted $3.0 \mathrm{~m}$ apart while oil palm was planted $9 \mathrm{~m}$ apart. Equal size of land area was used for coffee in each treatment. The experimental design was Randomized Complete Block (RCBD) with three replicates. Data on vegetative growth of coffee, weed incidence and biomass were taken at three-monthly intervals. The result showed that coffee/oil palm (Hollow Square) had the least weed incidence and biomass closely followed by coffee/oil palm (Avenue) planting. The control had the highest weed biomass which was significantly different from Hollow square and Avenue planting at $\mathrm{P} \leq 0.05$. The morphological parameters on coffee followed the same pattern but Hollow square arrangement was significantly higher than Avenue and control at $\mathrm{P} \leq 0.05$.
\end{abstract}

\section{Keywords}

Evaluation, Weed, Incidence, Biomass, Coffee, Intercropped, Oil Palm, Hollow Square, Avenue Arrangement 


\section{Introduction}

Weed flora has changed over the past century, with either increasing or decreasing species abundance depending on the management [1] [2] [3]. In an integrated approach, the development of cropping systems such as appropriate spatial arrangements and the efficient intercropping systems will help crops themselves to compete with weeds [4]. Manipulation of cropping systems for the purpose of improving integrated weed management requires a good understanding of weed dynamics and influences of crop and soil-related factors on weed life cycles [5].

Weeds have been implicated as the most damaging of crop pests because weed communities continue to adapt in response to new management measures [6]. Weed presence may cause more problems in some cropping systems, especially in organic farming where application of systemic agrochemicals is not allowed. Belde et al. [7] found that the composition of weed seed in the soil seed bank hardly changed six years after converting a farm from conventional to organic systems. However, many other investigators showed positive effect of cropping systems on biodiversity of farm lands [8] [9] [10]. Weed seed banks may reflect the status of weed population in the present and the past and could be regarded as an indicator of the impact of crop management [11]. Furthermore, weed causes reduction in crop yield and extra cost in the total labour use in crop production. Akobundu [12] stated that weed causes $65 \%$ reduction in yield of root and tuber crops and takes $25 \%$ of total labour use in production. Weed control constitutes the greatest problem during the early year of field establishment of coffee plant when they have not formed sizeable canopy [13]. Weed still appears to be the most deleterious constraint causing berry yield reduction. It is one of the commonest agronomic problems in coffee after planting on the field [14].

Hoe weeding which is the traditional method of weed control in Nigeria is very expensive, labour intensive, time consuming and exposes coffee soil to erosion [15]. Herbicides are very expensive for peasant farmers who are the major coffee growers in Nigeria. The current high cost of labour and unavailability of herbicide have necessitated the need for the cropping system manipulation to reduce weed incidence in coffee and equally improve its vigour and survival rate at early year of field establishment before the canopy closes.

Weed control through farming system practice of planting food crops has been found to suppress weed [16] [17] [18]. Intercropping had been reported to increase crop diversity, biological stability of the ecosystem and labour efficiency [19]. Intercropping in coffee to provide food and income for the farmers is usually possible at the juvenile stage before the leaf canopy closes [20]. With the global food crisis, intercropping coffee with tree crops of economic value that can still be together for years beyond the juvenile stage is of vital importance. Therefore, the objective of this study was to evaluate the incidence and biomass of weed in coffee intercropped with oil palm in Avenue planting and Hollow square arrangement. 


\section{Materials and Methods}

The study was carried out in Cocoa Research Institute of Nigeria (CRIN) in two locations between year 2012 and 2013 covering two rainy seasons and two dry seasons. The rainy season which runs from April to October is characterized by heavy rains, low ambient temperature and high humidity; while dry season running from November to March is characterized by little or no rain, high ambient temperature and very low humidity. The locations are Idi-Ayunre $\left(7^{\circ} 25^{\prime} \mathrm{N}\right.$, $3^{\circ} 24^{\prime} \mathrm{E}$ ) (an alfisol) and Uhonmora $\left(6^{\circ} 5^{\prime} \mathrm{N}, 5^{\circ} 50^{\prime} \mathrm{E}\right.$ ) (an ultisol) in rainforest and derived savanna zones of Nigeria respectively.

The coffee (Coffee canephora) seeds were obtained from CRIN research plot and raised into seedlings in CRIN central nursery. Oil palm seedlings (Tenera variety) were obtained from National Institute for Oil Palm Research (NIFOR), Benin City, Edo State, Nigeria. Plantain suckers were obtained from CRIN as shade for coffee seedlings at establishment.

The experiment had three treatments comprising of coffee sole (control), coffee/oil palm (Avenue) planting and coffee/oil palm (Hollow square) arrangement. The experiment was laid out in randomized complete block design with three replications. In Avenue planting, one line in three of palms omitted and the space planted with coffee. Hollow square treatment was created by omitting one palm out of each square of nine palms planted with coffee; while control was pure stands of coffee and pure stand of oil palm (Figure 1). Coffee was planted 3 $\mathrm{m} \times 3 \mathrm{~m}$ plant spacing, while oil palm was planted $9 \mathrm{~m} \times 9 \mathrm{~m}$. The plantain was planted at $3 \mathrm{~m} \times 3 \mathrm{~m}$ as shade crop at different geometry of coffee.

Weeding was carried regularly at 3 months interval during the experiment. Quadrants of $30 \mathrm{~cm} \times 30 \mathrm{~cm}$ were used to take weed samples per treatment before each time of weeding.

Data collected on physical and chemical properties of the soil at the beginning of the experiment through soil sampling and laboratory assay. Weed species were identified and collected by throwing a $30 \times 30 \mathrm{~cm}$ quadrant three times per plot. Fresh and dry weight of the weed after oven drying for 72 hours to a constant weight at $85^{\circ} \mathrm{C}$ was determined. The results obtained were subjected to statistical analysis and LSD was used to separate the means that were significant.

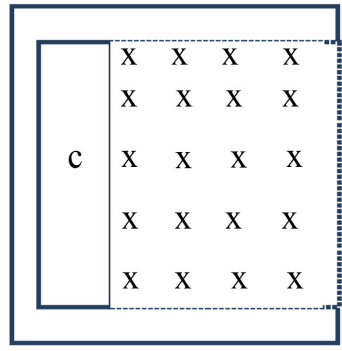

Coffee Sole

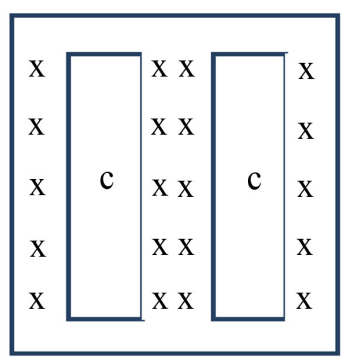

Coffee Avenue



Coffee Hollow Square

Figure 1. Lay-out of the different arrangements of intercrop of oil palm with coffee. Key: C: Coffee stands; X: Oil palm stands. 


\section{Results and Discussion}

The result of the initial physical and chemical properties of the soils used for the experiments is presented in Table 1. The particle-size analysis of the soils of both Idi-Ayunre and Uhonmora experimental sites showed that the soils were sandy loam, Alfisols and Utisols respectively [21]. The silt and clay contents of the soils at both locations (18.40\% and $21.20 \%$ ) were below the $32 \%$ estimated to be adequate for soils considered to be ideal for tree crops production especially coffee [22]. Based on the established critical levels for soils in South-Western Nigeria, the soils at Idi-Ayunre and Uhonmora were acidic with $\mathrm{pH}$ ranging between 6.2 - 5.2. The total nitrogen of both Idi-Ayunre and Uhonmora soils $(0.07 \%$ and $0.09 \%)$ was less than $0.15 \%$ which is considered optimal for most crops including coffee. The soils also had low CEC [23]. The available P (7.40 and $7.15 \mathrm{mg} / \mathrm{kg}$ for Idi-ayunre and Uhonmora respectively) is considered inadequate for coffee and oil-Palm [22]. Only Uhonmora soil gave exchangeable potassium below the critical value of $0.3 \mathrm{cmol} / \mathrm{kg}$ required for coffee. The exchangeable $\mathrm{Ca}^{2+}$ of both locations fell below the critical value of $5 \mathrm{cmol} / \mathrm{kg}$ required for coffee growth. Again, at both locations, the exchangeable $\mathrm{Mg}^{2+}$ was inadequate for coffee production. Obatolu [24] earlier observed the general low $\mathrm{Mg}^{2+}$ nutrient content of coffee soils in southern part of Nigeria. The low nutrient contents of the soils implied the need for external input of nutrients in order to meet the requirements for optimal coffee growth. It is obvious that the soils of both Idi-Ayunre and Uhonmora were inherently low in fertility and were therefore expected to show positive response to soil amendment.

Predominant weed species observed in the plots are indicated in Table 2. The weeds were more of annual broad leaf weeds than grasses and sedges. Weed incidence was more prevalent in Idi-Ayunre than in Uhonmora. This might probably be as a result of the fact that Idi-Ayuunre was in Rain Forest zone with

Table 1. Physical and chemical soil properties of the experimental sites.

\begin{tabular}{ccc}
\hline Soil Properties & Idi-Ayunre & Uhonmora \\
\hline $\mathrm{pH}\left(\mathrm{H}_{2} \mathrm{O}\right)$ & 6.2 & 5.2 \\
\% Organic carbon & 0.75 & 0.84 \\
\% Total Nitrogen & 0.07 & 0.09 \\
Available P (mg/kg) Soil & 7.40 & 7.15 \\
Exchangeable K (cmol/kg) Soil & 0.42 & 0.05 \\
Exchangeable Ca (cmol/kg) Soil & 2.45 & 2.65 \\
Exchangeable Mg (cmol/kg) Soil & 0.03 & 0.04 \\
Exchangeable Na (cmol/kg) Soil & 0.01 & 0.02 \\
$\%$ Sand & 81.60 & 78.8 \\
\% Clay & 10.0 & 12.0 \\
\% Silt & 8.40 & 9.2 \\
Soil Classification & Alfisol & Ultisol \\
\hline
\end{tabular}


Table 2. Common weed species present at the experimental sites and their level of occurrence.

\begin{tabular}{|c|c|c|c|c|}
\hline \multirow{3}{*}{ Weed species } & \multicolumn{4}{|c|}{ Level of infestation } \\
\hline & \multicolumn{2}{|c|}{ Idi-Ayunre } & \multicolumn{2}{|c|}{ Uhonmora } \\
\hline & 2012 & 2013 & 2012 & 2013 \\
\hline \multicolumn{5}{|l|}{ Broad leaf weeds } \\
\hline Euphorbia hirta L. & ++ & + & + & + \\
\hline Euphorbia Heterophylla L. & ++ & ++ & ++ & ++ \\
\hline Talinum triangulare (Jacq) Wild & + & ++ & ++ & ++ \\
\hline Tridax procumbens $\mathrm{L}$. & + & + & + & + \\
\hline Ancanthospermum hispidum DC & ++ & ++ & ++ & ++ \\
\hline Aspillia Africana (Pers) CD Adams & +++ & ++ & ++ & ++ \\
\hline $\begin{array}{l}\text { Chromolaena odorata (L.) R.M. King } \\
\text { and Robinson }\end{array}$ & +++ & ++ & +++ & ++ \\
\hline Amaranthus viridis $\mathrm{L}$. & ++ & ++ & + & + \\
\hline Solanum nigrum $\mathrm{L}$. & + & + & + & + \\
\hline \multicolumn{5}{|l|}{ Grasses } \\
\hline Cynodon dactylon (L.) Prs & + & + & + & + \\
\hline Eleusine indica Gaertn & + & + & + & + \\
\hline Panicum maximum Jacq & ++ & ++ & ++ & + \\
\hline Chloris pilasa (Scham) & + & + & + & + \\
\hline \multicolumn{5}{|l|}{ Sedges } \\
\hline Cyperus rotundus $\mathrm{L}$. & + & + & + & + \\
\hline Cyperus esculentum $\mathrm{L}$. & + & + & + & + \\
\hline Cyperus deformis $\mathrm{L}$. & + & + & + & + \\
\hline
\end{tabular}

more rains, while Uhonmora was in Derived Savanna. Also, there was less weed infestation in the second year compared to the first year in both locations. The higher vegetative growth of coffee and oil palm in the second year might be responsible for this. This shows that weed infestation might have constituted a major set-back to coffee production in early stage of field establishment, especially before the canopy closed. This is in consonance with CRIN [13] which found out that weed constituted the greatest problem of coffee production during the early year of field establishment before they formed sizeable canopy. It was also reported that weed was the commonest agronomic problem in coffee on the field [14].

Figure 2 shows the weed biomass at both locations. The highest weed biomass was recorded in the control treatment followed by Avenue with the least in Hollow square arrangement. This suggests the exposure of the ground surface of control treatment to more insolation. The significant less weed biomass in the hollow square arrangement plots suggests lesser weed incidence and lower labour 



Figure 2. Effects of avenue and hollow square arrangements of coffee intercropped with oil palm on weed biomass at Idi-Ayunre and Uhonmora.

requirement for weeding compared to the control plots. This also implies that coffee/oil palm in Hollow square arrangement is a better cropping system than other treatments. This agrees with the earlier work of Adeyemi [25] that reported appropriate intercropping system of food crop combinations that would increase labour efficiency in coffee production. It also corroborates Famaye [16] who reported that coffee/plantain farming system suppressed weed growth. Similarly, Santos et al. [20] had reported a reduced weed infestation in coffee intercrop with herbaceous legumes. This underscores the significance of intercropping system in the control of weed in coffee farms.

The plant height and leaf area of coffee are shown in Table 3 and Table 4 respectively. Coffee in Hollow square was higher in plant height as well as leaf area than other treatments, although the difference was not significant $(P<0.05)$. The least incidence of weed under coffee Hollow square and the consequent less competition from weeds for plant nutrients might have made nutrients more available for the coffee under this treatment, thus leading to better growth. The least growth was recorded in the control. The higher plant height and leaf area of 
Table 3. Mean plant height $(\mathrm{cm})$ of coffee intercropped with oil palm in hollow square and avenue arrangements.

\begin{tabular}{|c|c|c|c|c|c|c|c|c|c|}
\hline \multirow{2}{*}{ Location } & \multirow{2}{*}{ Treatments } & \multicolumn{8}{|c|}{ Months after transplanting } \\
\hline & & 3 & 6 & 9 & 12 & 15 & 18 & 21 & 24 \\
\hline \multirow{5}{*}{ Idi-Ayunre } & $\begin{array}{l}\text { Coffee sole } \\
\text { (Control) }\end{array}$ & 20.1 & 30.0 & 39.0 & 43.1 & 47.2 & 49.7 & 58.3 & 70.7 \\
\hline & $\begin{array}{c}\text { Avenue } \\
\text { arrangement }\end{array}$ & 19.1 & 27.0 & 43.4 & 45.2 & 49.7 & 50.9 & 60.0 & 75.3 \\
\hline & $\begin{array}{c}\text { Hollow square } \\
\text { arrangement }\end{array}$ & 19.7 & 27.4 & 43.5 & 47.0 & 50.2 & 53.9 & 64.2 & 81.0 \\
\hline & Mean & 20.0 & 28.1 & 42.1 & 45.1 & 48.5 & 51.7 & 60.8 & 75.7 \\
\hline & LSD $(\mathrm{P}<0.05)$ & 8.99 & 4.48 & 9.95 & 2.24 & 3.01 & 7.98 & 7.78 & 12.02 \\
\hline \multirow{5}{*}{ Uhonmora } & $\begin{array}{c}\text { Coffee sole } \\
\text { (Control) }\end{array}$ & 15.7 & 22.0 & 30.1 & 35.6 & 39.9 & 42.3 & 47.4 & 52.5 \\
\hline & $\begin{array}{c}\text { Avenue } \\
\text { arrangement }\end{array}$ & 16.3 & 22.1 & 30.0 & 38.5 & 40.8 & 44.6 & 50.1 & 57.2 \\
\hline & $\begin{array}{l}\text { Hollow square } \\
\text { arrangement }\end{array}$ & 15.5 & 24.3 & 38.1 & 42.7 & 45.5 & 50.2 & 57.5 & 63.4 \\
\hline & Mean & 15.8 & 22.8 & 33.4 & 38.9 & 42.7 & 45.7 & 51.7 & 57.6 \\
\hline & LSD $(\mathrm{P}<0.05)$ & 1.03 & 3.23 & 10.38 & 8.86 & 7.47 & 10.07 & 12.98 & 18.31 \\
\hline
\end{tabular}

Table 4. Mean leaf area $\left(\mathrm{cm}^{2}\right)$ of coffee intercropped with oil palm in avenue and hollow square arrangements.

\begin{tabular}{|c|c|c|c|c|c|c|c|c|c|}
\hline \multirow{2}{*}{ Locations } & \multirow{2}{*}{ Treatments } & \multicolumn{8}{|c|}{ Months after transplanting } \\
\hline & & 3 & 6 & 9 & 12 & 15 & 18 & 21 & 24 \\
\hline \multirow{5}{*}{ Idi-Ayunre } & $\begin{array}{l}\text { Coffee sole } \\
\text { (Control) }\end{array}$ & 74.1 & 82.0 & 86.4 & 105.2 & 116.0 & 119.7 & 157.7 & 140.2 \\
\hline & $\begin{array}{c}\text { Avenue } \\
\text { arrangement }\end{array}$ & 73.0 & 82.1 & 87.8 & 110.3 & 121.5 & 130.3 & 142.6 & 149.0 \\
\hline & $\begin{array}{c}\text { Hollow square } \\
\text { arrangement }\end{array}$ & 79.0 & 87.7 & 93.5 & 117.9 & 130.3 & 141.5 & 132.5 & 164.1 \\
\hline & Mean & 75.4 & 83.9 & 89.2 & 111.1 & 122.6 & 130.5 & 144.0 & 151.1 \\
\hline & LSD $(\mathrm{P}<0.05)$ & 7.93 & 8.10 & 9.34 & 15.87 & 17.91 & 27.6 & 30.81 & 30.01 \\
\hline \multirow{6}{*}{ Uhonmora } & $\begin{array}{l}\text { Coffee sole } \\
\text { (Control) }\end{array}$ & 64.2 & 73.6 & 90.3 & 99.5 & 113.2 & 120.3 & 128.5 & 140.3 \\
\hline & $\begin{array}{c}\text { Avenue } \\
\text { arrangement }\end{array}$ & 64.1 & 75.5 & 97.8 & 105.3 & 119.0 & 128.1 & 134.7 & 148.7 \\
\hline & & & & & & & & & \\
\hline & $\begin{array}{c}\text { Hollow square } \\
\text { arrangement }\end{array}$ & 64.5 & 78.0 & 105.1 & 116.4 & 125.3 & 137.6 & 145.4 & 159.1 \\
\hline & Mean & 64.3 & 75.7 & 97.7 & 109.1 & 119.2 & 128.7 & 136.2 & 149.4 \\
\hline & LSD $(\mathrm{P}<0.05)$ & 0.52 & 4.48 & 18.37 & 21.32 & 15.02 & 21.51 & 72.22 & 23.38 \\
\hline
\end{tabular}

coffee in Hollow square arrangement than in the control confirms the finding of Obatolu et al. [14] on the possibility of intercropping coffee with other crops. 


\section{Conclusion and Recommendations}

The Hollow square arrangement of growing coffee with oil palm was found superior to Avenue arrangement and coffee sole cropping as it enhanced the growth of coffee as well as reduced weed infestation in coffee plantation. This Hollow square arrangement appears to be more profitable and could be recommended to Robusta coffee farmers in Nigeria.

\section{Conflicts of Interest}

The authors declare no conflicts of interest regarding the publication of this paper.

\section{References}

[1] Bagmet, L. (2000) Dynamic of the Segetal Element of Weed Flora in the Lower-Volga Region. Zeitschrift für Pflanzenkrankheiten und Pflanzenschutz, 17, 85-90.

[2] Marshall, E.J.P., Brown, V.K., Boatman, N.D., Lutman, P.J.W., Squire, G.R. and Ward, L.K. (2003) The Role of Weeds in Supporting Biological Diversity within Crop Fields. Weed Science, 43, 77-89. https://doi.org/10.1046/j.1365-3180.2003.00326.x

[3] Stoate, C., Boatman, D., Borralho, R.J., Carvalho, C.R., Desnoo, G.R. and Eden, P. (2002) Ecological Impacts of Arable Intensification in Europe. Journal of Environmental Management, 63, 337-365. https://doi.org/10.1006/jema.2001.0473

[4] Avola, G., Tuttobene, R., Gresta, F. and Abbate, V. (2008) Weed Control Strategies for Grain Legumes. Agronomy for Sustainable Development, 28, 389-395. https://doi.org/10.1051/agro:2008019

[5] Davis, A.S. and Liebman, M (2003) Cropping System Effects on Giant Fox Tail (Setariat Faberi) Demography: 1 Green Manure and Tillage Training. Weed Science, 51, 919-929. https://doi.org/10.1614/P2002-133A

[6] Sosnoski, L.M. and Cardina, J. (2006) Weed Seed Bank Community Composition in a 35-Year-Old Tillage and Rotation Experiment. Weed Science, 54, 263-273. https://doi.org/10.1614/WS-05-001R2.1

[7] Belde, M., Mattheis, A., Sprenger, B. and Albrecht, H. (2000) Long-Term Development of Yield Affected Weeds after the Change from Conventional to Integrated and Organic Farming. Zeitschrift für Pflanzenkrankheiten und Pflanzenschutz, 17, 291-301.

[8] Gruber, H., Haedel, K. and Broschewitz, B. (2000) Influence of Farming System on Weeds in Thresh Crops of Six-Year Crop Rotation. Zeitschrift für Pflanzenkrankheiten und Pflanzenschutz, 17, 33-40.

[9] Hald, A.B. (1999) Weed Vegetation (Wild Flora) of Long Established Organic versus Conventional Cereal Fields in Denmark. Annals of Applied Biology, 134, 307-314. https://doi.org/10.1111/j.1744-7348.1999.tb05269.x

[10] Van Elsen, T. (2000) Species Diversity as a Task for Organic Agriculture in Europe. Agriculture, Ecosystems \& Environment, 77, 101-109. https://doi.org/10.1016/S0167-8809(99)00096-1

[11] Buhler, D.D., Koher, K.A. Thompson, R.L. (2001) Weed Seed Bank Dynamics during Five-Year Crop Rotation. Weed Techniques, 15, 170-176. https://doi.org/10.1614/0890-037X(2001)015[0170:WSBDDA]2.0.CO;2 
[12] Akobundu, I.O. (1987) Weed Science in the Tropics, Principles and Practices. John Wiley and Sons, London, $522 \mathrm{p}$.

[13] CRIN (1989) Cocoa Research Institute of Nigeria Progress (In) Tree Crop Research. 2nd Edition, CRIN, 17.

[14] Obatolu, R.R., Okelana, F.A., Adeyemi, A.A., Fawole, E.A., Oduwole, O.O., Omolaja, S.S., Famaye, A.O. and Ojelade, K.T.M. (1998) Coffee Production Manual (Handbook of Recommendation).

[15] Moss, R.I. (1956) A Guide to Coffee Culture in Jamaica Department of Agriculture Jamaica. 55.

[16] Famaye, A.O. and Agboola, A.A. (2003) Evaluation of Weed Biomass in Coffee Canephora Intercropped with Maize, Cassava, and Plantain in Nigeria. Journal of Weed Science, 16, 9-14.

[17] Feitas Santos, J.C., Junior da Cunha, A. and de Melo, B. (2014) Soil Cover and Weed Control on Coffee Intercropping Perennial Legume. International Journal of Applied Sciences and Technology, 4, 149-158.

[18] Nchangi, Y.K., Nkongho, R.N., Mala, W.A. and Levang, P. (2016) Efficacy of Oil Palm Intercropping by Smallholders. Case Study in South-West Cameroon. Agroforestry System, 90, 509-519. https://doi.org/10.1007/s10457-015-9873-Z

[19] Stomp, D. (2017) Smallholder Oil Palm: Space for Diversification? Wageningen University, Wageningen, $78 \mathrm{p}$.

[20] Feitas Santos, J.C., Junior da Cunha, A., Ferreira, F.A., Santos, R.H.S., Sakuyama, N.S. and de Lima, P.C. (2016) Herbaceous Legumes Intercropping in Weed Management of the Coffee Crop. Journal of Agriculture and Environmental Sciences, 5, 91-100.

[21] Soil Survey Staff (1999) Soil Taxonomy. A Basic System for Soil Classification for Making and Interpreting Soil Surveys. USDA Handbook, No. 436, Washington DC.

[22] Egbe, N.E., Ayodele, E.A. and Obatolu, C.R. (1989) Soil and Nutrition of Cocoa, Coffee, Kola. Cashew and Tea. In: Progress in Tree Crop Research in Nigeria, 2nd Edition, CRIN, Ibadan, 27-38.

[23] Ogunwale, J.A., Olaniyan, J.O. and Aduloju, M.O. (2002) Morphological, Physico-Chemical and Clay Mineralogical Properties of Soils Overlaying Basement Complex Rocks in Ilorin East, Nigeria. Moor Journal of Agricultural Research, 3, 147-154.

[24] Obatolu, C.R. (1991) Growth and Nutrient Uptake of Coffee (Coffea spp) Seedlings Grown on Different Organic Materials. Ph.D. Thesis, University of Ibadan, Ibadan, $276 \mathrm{p}$.

[25] Adeyemi, A.A. (1997) Intercropping Coffee with Arable in Tree Crops. In: Proceeding on Coffee Production Technology Transfer Workshop, ABU College of Agriculture, Kabba Kogi State, 39-46. 